\title{
Remobilization of Storage Nitrogen in Young Pear Trees Grafted onto Vigorous Rootstocks (Pyrus betulifolia)
}

\author{
Yang $\mathrm{Wu}^{1}{ }^{1}$ Mingde Sun ${ }^{1}$, Yuanyong $\mathrm{Qi}^{1}$ and Songzhong Liu ${ }^{2, *}$ \\ 1 Key Laboratory of Biology and Genetic Improvement of Horticultural Crops (North China), \\ Beijing Engineering Research Center for Deciduous Fruit Trees, Beijing Academy of Forestry and \\ Pomology Sciences, Ministry of Agriculture, Beijing 100093, China; wuyang1983_wy@163.com (Y.W.); \\ 13521361007@163.com (M.S.); qiyuanyong2008@126.com (Y.Q.) \\ 2 Beijing Academy of Forestry and Pomology Sciences, Ministry of Agriculture, Beijing 100093, China \\ * Correspondence: szliu1978@163.com; Tel.: +86-10-62859388
}

check for updates

Citation: Wu, Y.; Sun, M.; Qi, Y.; Liu, S. Remobilization of Storage Nitrogen in Young Pear Trees Grafted onto Vigorous Rootstocks (Pyrus betulifolia). Horticulturae 2021, 7, 148. https:// doi.org/10.3390/horticulturae7060148

Academic Editor:

Francisco Garcia-Sanchez

Received: 28 April 2021

Accepted: 8 June 2021

Published: 10 June 2021

Publisher's Note: MDPI stays neutral with regard to jurisdictional claims in published maps and institutional affiliations.

Copyright: (c) 2021 by the authors. Licensee MDPI, Basel, Switzerland. This article is an open access article distributed under the terms and conditions of the Creative Commons Attribution (CC BY) license (https:// creativecommons.org/licenses/by/ $4.0 /)$.

\begin{abstract}
The remobilization of storage nitrogen $(\mathrm{N})$ is affected by growth characteristics of young pear trees. Aboveground parts of young pear trees grafted on P. betulifolia grew more vigorously than that on dwarfing rootstocks. Therefore, the remobilization of storage $\mathrm{N}$ within young pear trees on vigorous rootstocks may be different from that on dwarfing rootstocks. ${ }^{15} \mathrm{~N}$ tracing experiment, including six groups of one-year-old pear trees grafted on vigorous rootstocks in 2016, was conducted to investigate the mobilization of storage N from 2016 to 2018. Results indicated that about $44 \%$, $31.4 \%$ and $24.6 \%$ of storage $\mathrm{N}$ remobilized in new growth was derived from the trunk, shoots and roots, respectively. Most of storage $\mathrm{N}$ remobilized in new organs were supplied by trunks and shoots. About $82.2 \%$ of storage $\mathrm{N}$ withdrawn from senescent leaves were recovered in the trunk and shoots during autumn. The aboveground parts played a more important role than roots in the cycling process of storage $\mathrm{N}$ in young pear trees. However, as compared with young pear trees on dwarfing rootstocks, more storage $\mathrm{N}$ recovered in new organs were supplied by roots of that on vigorous rootstocks, due to vigorous growth and more nutrient requirement of aboveground parts.
\end{abstract}

Keywords: labelled nitrogen; nitrogen derived from fertilizer; nitrogen concentration; new organs; perennial structures

\section{Introduction}

The remobilization of stored nitrogen $(\mathrm{N})$ is a key factor influencing $\mathrm{N}$ uptake, growth, development, and longevity of deciduous fruit trees [1-4]. The remobilization of $\mathrm{N}$ mainly occurs during two periods, including the early spring [5-7] and defoliation stage [8-11].

In early spring, the low soil temperatures result in minimal low activity in root systems, and the $\mathrm{N}$ to sustain new organ growth is mainly remobilized from the perennial tissues [9,12-15]. Studies on apple [16,17], walnut [18] and persimmon trees [19] show that approximately half of the total tree $\mathrm{N}$ amount is remobilized to sustain new organ growth. The researches on the fruit trees indicated the decline in $\mathrm{N}$ content of root system is far higher than that found in stems during the spring, and the root system contributes greatly to $\mathrm{N}$ storage during winter $[20,21]$. Similar results were concluded by the studies on the sycamore [22], nectarine [6], apple [23], walnut [24], persimmon [19], cherry [25,26] and peach trees [27]. However, the studies on the apple [28], pear [10] and walnut trees [29] concluded that the remobilized $\mathrm{N}$ of new growth in early spring is mainly supplied by the aboveground structures.

Studies on the remobilization of $\mathrm{N}$ stored in the perennial structures of pear trees during the early spring have been conducted [5,8,10,30-34]. The pear trees mentioned in these studies were $P$. communis L. grafted on the quince rootstocks (dwarfing rootstocks) or mature pear trees grafted on vigorous rootstocks. However, as compared with that on the quince rootstocks, the aboveground growth of young pear trees grafted on the 
P. betulifolia (a type of vigorous rootstocks) are more vigorous [35]. The obvious differences in root length density between the quince and P. betulifolia are also observed by Zhao et al. [35]. P. betulifolia is the major rootstock and has been widely used in pear orchards in North China [35]. $\mathrm{N}$ is one of the key nutrients affecting the growth of young pear trees. The $\mathrm{N}$ uptake of perennial structures is used to meet their own growth and support the new growth in next spring. The absorption and remobilization of $\mathrm{N}$ is affected by the characteristics of various structures' growth. Therefore, the remobilization of storage $\mathrm{N}$ in young pear trees on P. betulifolia may be different from that on the dwarfing rootstocks. Tagliavini et al. [32] also concluded that storage capacity is related to tree size and age, internal $\mathrm{N}$ cycling within trees grafted on vigorous rootstocks might be more essential in the overall $\mathrm{N}$ economy than on dwarfing rootstocks. Although the remobilization of storage $\mathrm{N}$ of mature pear trees grafted on vigorous rootstocks was reported by Jiang et al. [36], there were obviously differences in growth trends between mature and young pear trees. The studies on the remobilization of the reserve $\mathrm{N}$ stored in perennial structures of young pear trees (P. bretschneideri Rehd) grafted on the P. betulifolia rootstocks are scarce.

During leaf senescence, more than half of the leaf $\mathrm{N}$ is mobilized to the perennial parts of trees $[8,9,37]$, which sustains the growth of new organs in the next spring $[10,16,38-40]$. To date, researches mainly focus on the total amount of $\mathrm{N}$ withdrawn from senescent leaves $[8,34]$. The studies on the redistribution of stored $N$, withdrawn from leaves, in various perennial structures of young pear trees are scarce.

More than $60 \%$ chemical fertilizer is applied once before bud break stage by farmers in North China, which can save labor on the pear orchards in the following periods. Therefore, the investigation on the internal cycling of $\mathrm{N}$ taken up in early spring were necessary for improving nutrient use efficiency of young pear grafted on vigorous rootstocks. The study aimed to evaluate (1) the remobilization of stored $\mathrm{N}$ of young pear trees (P. bretschneideri Rehd) grafted on the P. betulifolia rootstocks during spring, (2) redistribution of stored $\mathrm{N}$ withdrawn from senescent leaves during autumn.

\section{Materials and Methods}

\subsection{Experimental Site and Materials}

The experiment was conducted in an experimental pear orchard in Haidian District (Beijing, China, $39^{\circ} 95^{\prime} \mathrm{N}, 116^{\circ} 03^{\prime}$ E) from March 2016 to June 2018. The experimental site has a continental monsoon climate with a mean annual precipitation amount and temperature of $550 \mathrm{~mm}$ and $12.8^{\circ} \mathrm{C}$, respectively. One-year-old pear trees (P. bretschneideri Rehd 'Huangguan') grafted on the rootstock of $P$. betulaefolia were planted in spring 2016. Spacing was $1 \mathrm{~m}$ within rows and $3.5 \mathrm{~m}$ between rows of trees $\left(2857\right.$ trees $\left.\cdot \mathrm{ha}^{-1}\right)$. The soil of the experimental orchard was clay loam with an average bulk density of $1.4 \mathrm{~g} \cdot \mathrm{cm}^{-3}$, and the soil $\mathrm{N}$ content at depth of $0-60 \mathrm{~cm}$ was $0.5 \mathrm{~g} \cdot \mathrm{kg}^{-1}$.

\subsection{Experimental Design}

The young pear trees were fertilized with the labelled $\mathrm{N}$ once in early spring, to evaluate the remobilization of labelled $\mathrm{N}$ in the next years. The experimental trees were divided into groups A, B, C, D, E and F. The groups A, B, D and E were fertilized with $10 \mathrm{~g}$ unlabelled and $5 \mathrm{~g}$ labelled $\mathrm{N}$ (enriched to 10.19 atom $\%{ }^{15} \mathrm{~N}$ ) per tree, the groups $\mathrm{C}$ and $\mathrm{F}$ were fertilized with $15 \mathrm{~g}$ unlabelled $\mathrm{N}$ per tree in 2016. The groups $\mathrm{B}$ and $\mathrm{F}$ were fertilized with $20 \mathrm{~g}$ unlabelled $\mathrm{N}$ per tree, the groups $\mathrm{C}, \mathrm{D}$ and $\mathrm{E}$ were fertilized with $15 \mathrm{~g}$ unlabelled and $5 \mathrm{~g}$ labelled $\mathrm{N}$ per tree in 2017. The group $\mathrm{E}$ was fertilized with $30 \mathrm{~g}$ unlabelled $\mathrm{N}$ per tree, the group F was fertilized with $25 \mathrm{~g}$ unlabelled and $5 \mathrm{~g}$ labelled $\mathrm{N}$ per tree in 2018 (Table 1). The urea-N fertilizer was dissolved in water and sprinkled evenly onto the soil before bud break stage (March 20) each year. The treated ground was immediately covered with soil to prevent ammonia volatilization [30]. The experiment had a randomized design and was repeated three times. Each repetition in groups B, C and D consisted of 4 trees, and each repeat in the other groups consisted of 2 trees. 
Table 1. The timing and rate of fertilization of pear trees divided according to their groups.

\begin{tabular}{cccc}
\hline Group & 2016 & 2017 & $\mathbf{2 0 1 8}$ \\
\hline $\mathrm{A}$ & $10 \mathrm{~g} /$ tree $\bigcirc+5 \mathrm{~g} /$ tree $\bullet$ & - & - \\
$\mathrm{B}$ & $10 \mathrm{~g} /$ tree $\bigcirc+5 \mathrm{~g} /$ tree $\bullet$ & $20 \mathrm{~g} /$ tree $\bigcirc$ & - \\
$\mathrm{C}$ & $15 \mathrm{~g} /$ tree $\bigcirc$ & $15 \mathrm{~g} /$ tree $\bigcirc+5 \mathrm{~g} /$ tree $\bullet$ & - \\
$\mathrm{D}$ & $10 \mathrm{~g} /$ tree $\bigcirc+5 \mathrm{~g} /$ tree $\bullet$ & $15 \mathrm{~g} /$ tree $\bigcirc+5 \mathrm{~g} /$ tree $\bullet$ & - \\
$\mathrm{E}$ & $10 \mathrm{~g} /$ tree $\bigcirc+5 \mathrm{~g} /$ tree $\bullet$ & $15 \mathrm{~g} /$ tree $\bigcirc+5 \mathrm{~g} /$ tree $\bullet$ & $30 \mathrm{~g} /$ tree $\bigcirc$ \\
$\mathrm{F}$ & $15 \mathrm{~g} /$ tree $\bigcirc$ & $20 \mathrm{~g} /$ tree $\bigcirc$ & $25 \mathrm{~g} /$ tree $\bigcirc+5 \mathrm{~g} /$ tree $\bullet$ \\
\hline
\end{tabular}

Note: $\bigcirc$ means unlabelled $\mathrm{N}$; $\bullet$ means labelled $\mathrm{N}$ (enriched to 10.19 atom $\%{ }^{15} \mathrm{~N}$ ); - means no fertilization.

\subsection{Measurements}

The trees in group A were harvested on June 10 and November 20, 2016. The trees in groups B, C and D were harvested on June 10 and November 20, 2017, and those in groups E and F were harvested on June 10, 2018 (Table 2). Six trees per group were harvested at each sampling time. Six more of the same trees were harvested in March 2016 to evaluate the initial dry weight and $\mathrm{N}$ content of each organs. The trees were removed from the soil and separated into trunk, leaves, shoots, 2 and 3 year old branches, fruits and roots. All plant structures were washed, dried to constant weight at $70{ }^{\circ} \mathrm{C}$, weighed to measure the dry matter, ground $(<0.25 \mathrm{~mm})$, and then analyzed for total $\mathrm{N}$ and $\%{ }^{15} \mathrm{~N}$ enrichment. Total N was determined using a Kjeldahl azotometer (QSY-II, Beijing Qiangsheng Analysis Instrument Manufacturing Centre, China). The $\%{ }^{15} \mathrm{~N}$ enrichment was determined using an isotope ratio mass spectrometer (MAT251, Thermo Finnigan, San Francisco, CA, USA). The dry mass weight and $\mathrm{N}$ content in each organ of the pear trees at the beginning of the experiments are shown in Table 3.

Table 2. The harvest sampling time and quantity of pear trees of each group.

\begin{tabular}{|c|c|c|c|c|}
\hline \multirow{2}{*}{ Group } & \multirow{2}{*}{$\begin{array}{l}2016 \\
\text { Nov. }\end{array}$} & \multicolumn{2}{|c|}{2017} & \multirow{2}{*}{$\begin{array}{c}2018 \\
\text { Jun. }\end{array}$} \\
\hline & & Jun. & Nov. & \\
\hline A & 6 trees & & & \\
\hline B & & 6 trees & 6 trees & \\
\hline $\mathrm{C}$ & & 6 trees & 6 trees & \\
\hline $\mathrm{D}$ & & 6 trees & 6 trees & \\
\hline E & & & & 6 trees \\
\hline $\mathrm{F}$ & & & & 6 trees \\
\hline
\end{tabular}

Table 3. The dry mass weight, $\mathrm{N}$ content and concentration of each pear tree structure.

\begin{tabular}{|c|c|c|c|c|}
\hline Years & Organs & N Content (mg) & Dry Mass Weight (g) & $\mathrm{N}$ Concentration $(\%)$ \\
\hline \multirow{3}{*}{$\begin{array}{l}\text { Mar. } 2016 \\
\text { Nursery }\end{array}$} & Trunk & $278.7 \pm 14.8 \mathrm{c} \mathrm{E}$ & $43.2 \pm 1.4 \mathrm{~b} \mathrm{D}$ & $0.64 \pm 0.02 \mathrm{~b} \mathrm{C}$ \\
\hline & Roots & $485.0 \pm 15.8 \mathrm{~b} \mathrm{D}$ & $42.3 \pm 1.1 \mathrm{~b} \mathrm{D}$ & $1.14 \pm 0.06$ a B \\
\hline & Total & $763.7 \pm 11.7$ a E & $85.6 \pm 2.3$ a E & \\
\hline \multirow{5}{*}{ Nov. 2016} & Leaves & $89.6 \pm 10.4 \mathrm{~d} D$ & $6.9 \pm 0.8 \mathrm{~d} D$ & $1.30 \pm 0.01 \mathrm{a} \mathrm{D}$ \\
\hline & Shoots & $168.4 \pm 20.0 \mathrm{~d} D$ & $13.2 \pm 1.3 \mathrm{c} \mathrm{E}$ & $1.27 \pm 0.04 \mathrm{a} A$ \\
\hline & Trunk & $668.8 \pm 39.0$ c D & $65.8 \pm 4.6 \mathrm{~b} \mathrm{D}$ & $1.01 \pm 0.03 \mathrm{c} \mathrm{A}$ \\
\hline & Roots & $789.6 \pm 45.6 \mathrm{~b} \mathrm{C}$ & $64.6 \pm 3.8 \mathrm{~b} \mathrm{CD}$ & $1.22 \pm 0.03 \mathrm{~b} \mathrm{~A}$ \\
\hline & Total & $1716.4 \pm 86.2$ a D & $150.5 \pm 8.2$ a D & \\
\hline \multirow{6}{*}{ Jun. 2017} & Leaves & $2286.3 \pm 178.2 \mathrm{~b} \mathrm{~B}$ & $86.8 \pm 6.7$ с B & $2.64 \pm 0.01 \mathrm{a} \mathrm{B}$ \\
\hline & Shoots & $345.3 \pm 27.2 \mathrm{~d} \mathrm{C}$ & $38.1 \pm 3.2 \mathrm{~d} D$ & $0.91 \pm 0.08 \mathrm{c} \mathrm{D}$ \\
\hline & 2 years old branches & $129.3 \pm 4.6 \mathrm{~d} D$ & $16.3 \pm 0.5 \mathrm{~d} \mathrm{E}$ & $0.79 \pm 0.01 \mathrm{~d} E$ \\
\hline & Trunk & $1035.3 \pm 80.9$ c C & $168.7 \pm 12.7 \mathrm{~b} \mathrm{C}$ & $0.61 \pm 0.01$ e C \\
\hline & Root & $1042.5 \pm 67.0$ с C & $84.6 \pm 5.0$ с C & $1.23 \pm 0.01 \mathrm{~b} \mathrm{~A}$ \\
\hline & Total & $4838.7 \pm 332.6$ a C & $394.5 \pm 26.2$ a C & \\
\hline
\end{tabular}


Table 3. Cont.

\begin{tabular}{ccccc}
\hline Years & Organs & N Content (mg) & Dry Mass Weight (g) & N Concentration (\%) \\
\hline & Leaves & $738.3 \pm 66.4 \mathrm{e} \mathrm{C}$ & $50.6 \pm 5.2 \mathrm{e} \mathrm{C}$ & $1.46 \pm 0.02 \mathrm{a} \mathrm{C}$ \\
& Shoots & $1554.6 \pm 149.6 \mathrm{~d} \mathrm{~A}$ & $140.8 \pm 15.8 \mathrm{~d} \mathrm{~B}$ & $1.11 \pm 0.03 \mathrm{c} \mathrm{B}$ \\
Nov. 2017 & $180.2 \pm 13.6 \mathrm{f} \mathrm{D}$ & $17.7 \pm 1.6 \mathrm{e} \mathrm{E}$ & $1.02 \pm 0.05 \mathrm{~d} \mathrm{C}$ \\
& 2 years old branches & $3832.6 \pm 203.1 \mathrm{~b} \mathrm{~B}$ & $455.6 \pm 34.0 \mathrm{~b} \mathrm{~B}$ & $0.84 \pm 0.02 \mathrm{e} \mathrm{B}$ \\
& Roots & $3211.6 \pm 174.3 \mathrm{c} \mathrm{B}$ & $253.2 \pm 20.6 \mathrm{c} \mathrm{B}$ & $1.27 \pm 0.07 \mathrm{~b} \mathrm{~A}$ \\
& Total & $9517.3 \pm 584.4 \mathrm{a} \mathrm{B}$ & $917.9 \pm 74.5 \mathrm{a} \mathrm{B}$ & \\
\hline & Leaves & $8099.7 \pm 541.4 \mathrm{~b} \mathrm{~A}$ & $295.0 \pm 24.7 \mathrm{~d} \mathrm{~A}$ & $2.75 \pm 0.07 \mathrm{a} \mathrm{A}$ \\
& Shoots & $1150.5 \pm 124.5 \mathrm{ef} \mathrm{B}$ & $117.7 \pm 12.3 \mathrm{f} \mathrm{C}$ & $0.98 \pm 0.02 \mathrm{~d} \mathrm{C}$ \\
Jun. 2018 & $1456.3 \pm 108.5 \mathrm{e} \mathrm{A}$ & $208.7 \pm 16.3 \mathrm{e} \mathrm{A}$ & $0.70 \pm 0.01 \mathrm{f} \mathrm{F}$ \\
& $248.9 \pm 22.9 \mathrm{~g} \mathrm{CD}$ & $23.0 \pm 2.1 \mathrm{~g} \mathrm{D} \mathrm{E}$ & $1.08 \pm 0.01 \mathrm{c} \mathrm{B}$ \\
& 2 years old branches & $632.1 \pm 32.0 \mathrm{~b} \mathrm{~A}$ & $0.52 \pm 0.02 \mathrm{~g} \mathrm{D}$ \\
& Trunk & $3263.5 \pm 194.1 \mathrm{~d} \mathrm{~A}$ & $406.7 \pm 27.7 \mathrm{c} \mathrm{A}$ & $1.21 \pm 0.01 \mathrm{~b} \mathrm{AB}$ \\
& Roots & $4914.6 \pm 311.8 \mathrm{c} \mathrm{A}$ & $51.1 \pm 4.8 \mathrm{fg}$ & $0.91 \pm 0.01 \mathrm{e}$
\end{tabular}

Note: The numbers are mean \pm standard deviation $(n=6)$. Different small letters in the same column and for each sampling time indicate significant differences $(p<0.05)$ among organs; different capital letters in the same columns, for the same organ, indicate significant differences $(p<0.05)$ among sampling times. Shoots and branches were regarded as the same organ for variance analysis among sampling times.

\subsection{Calculations and Data Analysis}

Nitrogen derived from the ${ }^{15} \mathrm{~N}$-fertilizer in each plant structure (\%Ndff) represented the contribution percentage of $\mathrm{N}$ uptake from the ${ }^{15} \mathrm{~N}$-fertilizer and was determined in accordance with the formula described by Carranca et al. [41]:

$$
\% \text { Ndff }=\frac{\text { at. } \%{ }^{15} \text { excess of sample }}{\text { at. } \%{ }^{15} \text { excess of labelled fertilizer }} \times 100 \pm
$$

where natural atom $\%{ }^{15} \mathrm{~N}$ is equal to 0.366 .

The amount of $\mathrm{N}$ derived from the fertilizer in different pear tree structures (NF) was determined by

$$
\begin{gathered}
\mathrm{NF}=\text { total } \mathrm{N} \text { in structure } \times \% \mathrm{Ndff} \times \frac{\text { amout of total fertilizer }}{\text { amout of labelled fertilizer }} \\
\qquad \mathrm{TNF}=\sum_{\text {all structures }} \mathrm{NF}
\end{gathered}
$$

where TNF represents the sum of NF in all structures of whole pear trees.

The trees in groups A and C were destructively sampled in 2016 and 2017, respectively. According to Equation (2), the NFA and NFC was defined as the amount of N derived from the fertilizer, which were applied in 2016 and 2017, in different pear tree structures of group $\mathrm{A}$ and $\mathrm{C}$ trees, respectively.

The trees in group B were destructively sampled in 2017, according to Equation (2), and the NFB was defined as the amount of $\mathrm{N}$ derived from the fertilizer, which was applied in 2016, in different pear tree structures of group B trees. The NFB consists of two parts: a. the amount of fertilizer- $\mathrm{N}$ taken up in $2016\left(\mathrm{NFB}_{2016}\right)$; $\mathrm{b}$. The amount of fertilizer-N taken up in $2017\left(\mathrm{NFB}_{2017}\right)$. The NFB was calculated as follows:

$$
\mathrm{NFB}=\mathrm{NFB}_{2016}+\mathrm{NFB}_{2017}
$$

The sum of NFB in all organs of a whole tree (TNFB) were calculated as follows:

$$
\mathrm{TNFB}=\mathrm{TNFB}_{2016}+\mathrm{TNFB}_{2017}
$$

where $\mathrm{TNFB}_{2016}$ and $\mathrm{TNFB}_{2017}$ represents the sum of $\mathrm{NFB}_{2016}$ and $\mathrm{NFB}_{2017}$ in all organs of a whole tree, respectively. 
The sum of NFA in all organs of a whole tree was equal to the sum of $\mathrm{NFB}_{2016}$ in all organs of a whole tree, thus

$$
\mathrm{TNFB}_{2016}=\mathrm{TNFA}
$$

where TNFA represents the sum of NFA in all organs of a whole tree.

According Equations (5) and (6), $\mathrm{TNFB}_{2017}$ were calculated as follows:

$$
\mathrm{TNFB}_{2017}=\mathrm{TNFB}-\mathrm{TNFA}
$$

We hypothesized that the ratio of NFC in some structures to TNFC was equal to the ratio of $\mathrm{NFB}_{2017}$ in the same structure to $\mathrm{TNFB}_{2017}$, so Equation (8) was calculated as follows:

$$
\frac{\text { NFC in some structure }}{\text { TNFC }}=\frac{\mathrm{NFB}_{2017} \text { in some structure }}{\mathrm{TNFC}_{2017}}
$$

Therefore, $\mathrm{NFB}_{2017}$ was calculated as follows:

$$
\begin{gathered}
\mathrm{NFB}_{2017} \text { in some structure }=\mathrm{TNFB}_{2017} \times \frac{\mathrm{NFC} \text { in some structure }}{\mathrm{TNFC}} \\
\mathrm{NFB}_{2016}=\mathrm{NFB}-\mathrm{NFB}_{2017}
\end{gathered}
$$

$\mathrm{NFB}_{2016}$ also represents the amount of the fertilizer-N, which was derived in 2016, in different pear tree structures in 2017. The calculation and data analysis was shown in Figure 1. In the following parts, the $\mathrm{NFB}_{2016}$ was abbreviated to $\mathrm{N}_{2016}$.

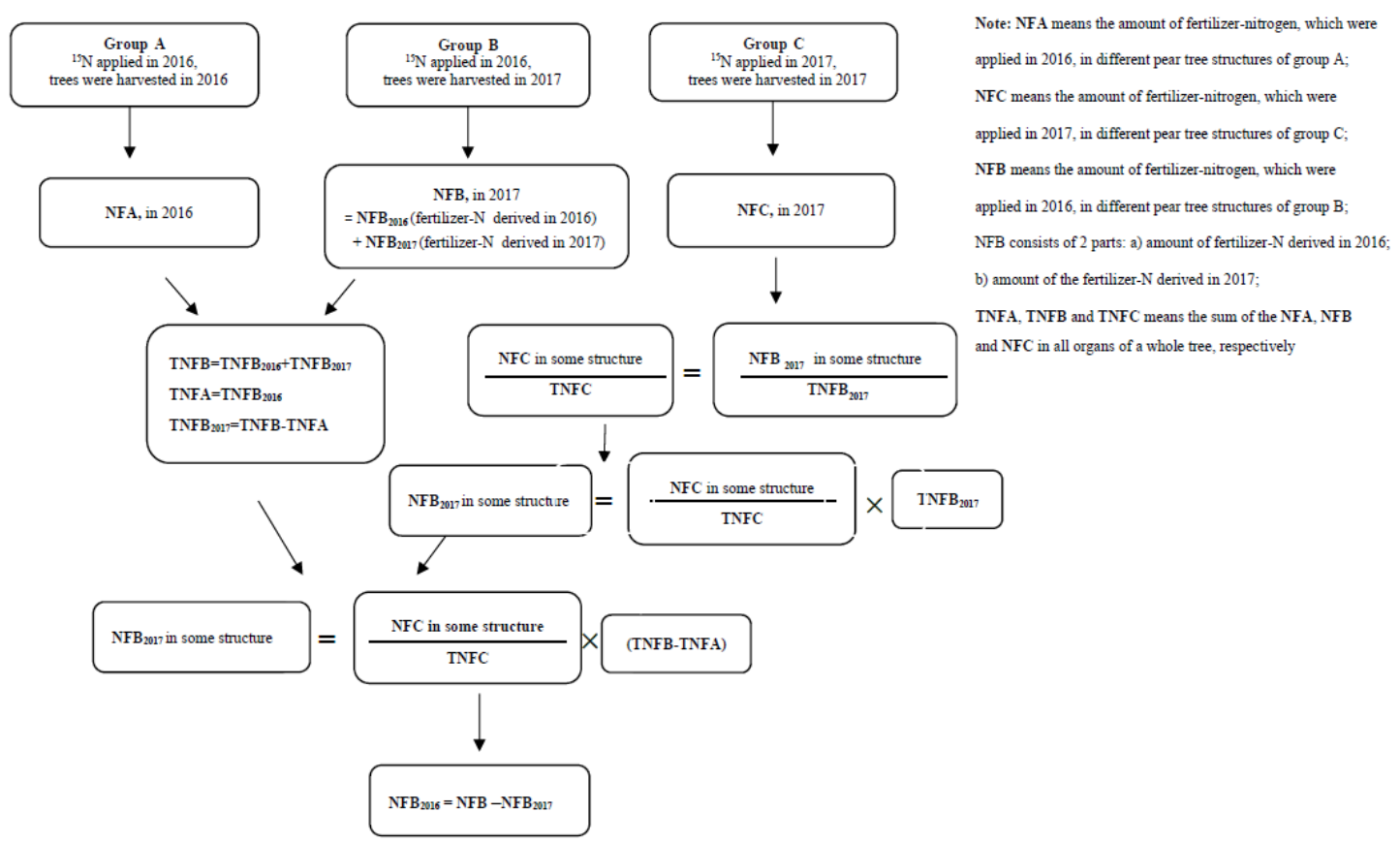

Figure 1. The calculation method of the amount of fertilizer-N, which was taken up in 2016, in each structure in 2017.

The amount of fertilizer-N, derived in 2016 and 2017, in the different structures of group $\mathrm{E}$ trees in 2018 was determined with the same method, and was abbreviated to $\mathrm{N}_{2016 \& 2017}$.

\subsection{Statistical Analysis}

Statistical analyses were conducted using SPSS 16.0 (SPSS Inc., Chicago, IL, USA). Means and standard deviations were calculated to show the measuring accuracy of each biological parameter. The measurements were analyzed with analyses of variance. Tukey 
tests were used to assess the differences between means and significant differences were based on $p<0.05$. All measurements were repeated six times.

\section{Results}

\subsection{The N Content and Concentration in Each Structure of Young Pear Trees}

From spring 2016 to June 2018, the total N content in whole pear trees increased from $0.76 \mathrm{~g}$ to $19.6 \mathrm{~g}$ (Table 3), and the $\mathrm{N}$ uptake from the soil was significantly higher than that from the fertilizer (Table 4). The $\mathrm{N}$ content was highest in the leaves, followed by the trunk and roots, and the lowest was in the branches and fruits in June 2017 and 2018 (Table 3). The highest $\mathrm{N}$ content were observed in trunk and roots in November 2016 and 2017. From June to November 2017, the N content in the leaves sharply declined, and accounted for less than $8 \%$ of that in whole pear trees (Table 3 ).

Table 4. The increment of total $\mathrm{N}$ of pear trees, $\mathrm{N}$ uptake from the fertilizer and the soil from March 2016 to June 2018.

\begin{tabular}{cccc}
\hline Time & $\begin{array}{c}\text { Increment of } \\
\text { Total N (mg) }\end{array}$ & $\begin{array}{c}\text { Increment of N } \\
\text { Uptake from } \\
\text { Fertilizer (mg) }\end{array}$ & $\begin{array}{c}\text { Increment of N } \\
\text { Uptake from Soil (mg) }\end{array}$ \\
\hline Mar. 2016 to Nov.2016 & $953 \pm 93 \mathrm{~d}$ & $285 \pm 11 \mathrm{c}$ & $668 \pm 88 \mathrm{~d}$ \\
Nov.2016 to Jun. 2017 & $3122 \pm 333 \mathrm{c}$ & $743 \pm 57 \mathrm{~b}$ & $2379 \pm 287 \mathrm{c}$ \\
Jun. 2017 to Nov. 2017 & $4679 \pm 584 \mathrm{~b}$ & $855 \pm 39 \mathrm{~b}$ & $3823 \pm 550 \mathrm{~b}$ \\
Nov. 2017 to Jun. 2018 & $10082 \pm 1178 \mathrm{a}$ & $2128 \pm 160 \mathrm{a}$ & $7954 \pm 1030 \mathrm{a}$ \\
\hline
\end{tabular}

Note: The numbers are mean \pm standard deviation $(n=6)$. Different small letters in the same column. indicate significantly differences $(p<0.05)$.

The highest $\mathrm{N}$ concentrations were observed in leaves throughout the whole experimental periods. The $\mathrm{N}$ concentrations in the roots kept constant $(1.2-1.3 \%)$ in three consecutive experimental years, except in March 2016. As compared with that in November, the $\mathrm{N}$ concentration in the trunk was significantly lower in the next June. The lower $\mathrm{N}$ concentration was observed in 2 year old branches in June, as compared with that in shoots in the previous November (Table 3).

\subsection{Stored N Remobilized in Spring and Withdrawn from Senescent Leaves in Autumn}

About $28.1 \%$ of the fertilizer- $\mathrm{N}$ derived in $2016\left(\mathrm{~N}_{2016}\right)$ within a whole tree was recovered in the leaves in June 2017 (Figure 2), which was far higher than that in the shoots, and similar results were observed in June 2018 (Figure 3). From November 2016 to the next spring, the $\mathrm{N}_{2016}$ stored in the trunk and 2 years old branches decreased 37.1 and $26.5 \mathrm{mg}$, respectively (Figure 2), which accounted for about $44.0 \%$ and $31.4 \%$ of the total $\mathrm{N}_{2016}$ remobilized in new organs (Figure 4). The decrease in $\mathrm{N}_{2016}$ stored in the trunk and 2 year old branches was higher than that in the roots (Figure 4), in particular the differences between the trunk and roots were significant, and similar results were observed in spring of 2018 (Figure 5). These results indicate that the $\mathrm{N}$ remobilized in new tissues was mainly supplied by the trunks and 2 year old branches of young pear trees. The $\mathrm{N}_{2016 \& 2017}$ derived from the 3 year old branches was $11.2 \mathrm{mg}$ in the spring of 2018, which was the lowest among all perennial tissues. 


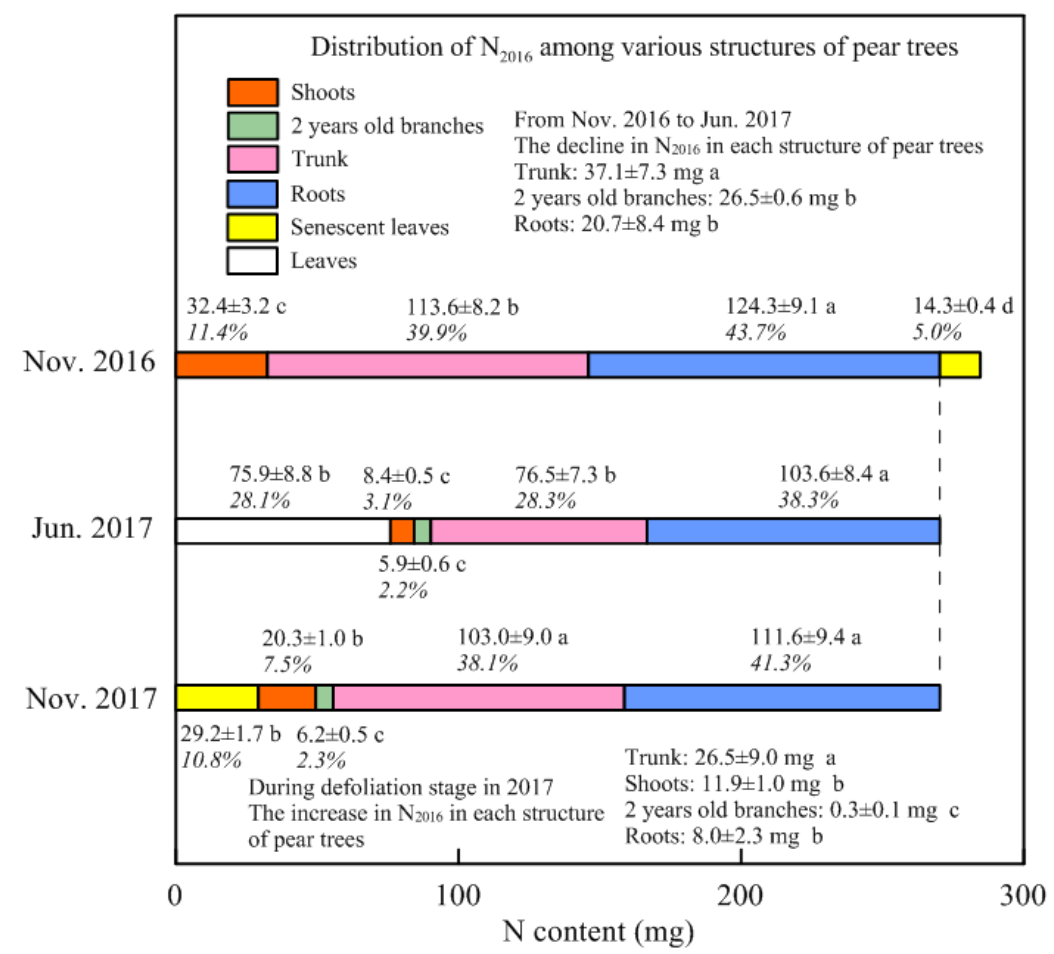

Figure 2. The distribution of $\mathrm{N}_{2016}$ among various structures of pear trees. $\mathrm{N}_{2016}$ means amount of fertilizer-N derived in 2016. The numbers means the $\mathrm{N}_{2016}$ amount in each structure. Different small letters for each sampling time indicate significant differences $(p<0.05)$ among organs. The italic numbers mean the ratio of $\mathrm{N}_{2016}$ in each structure to total $\mathrm{N}_{2016}$ in a whole tree.

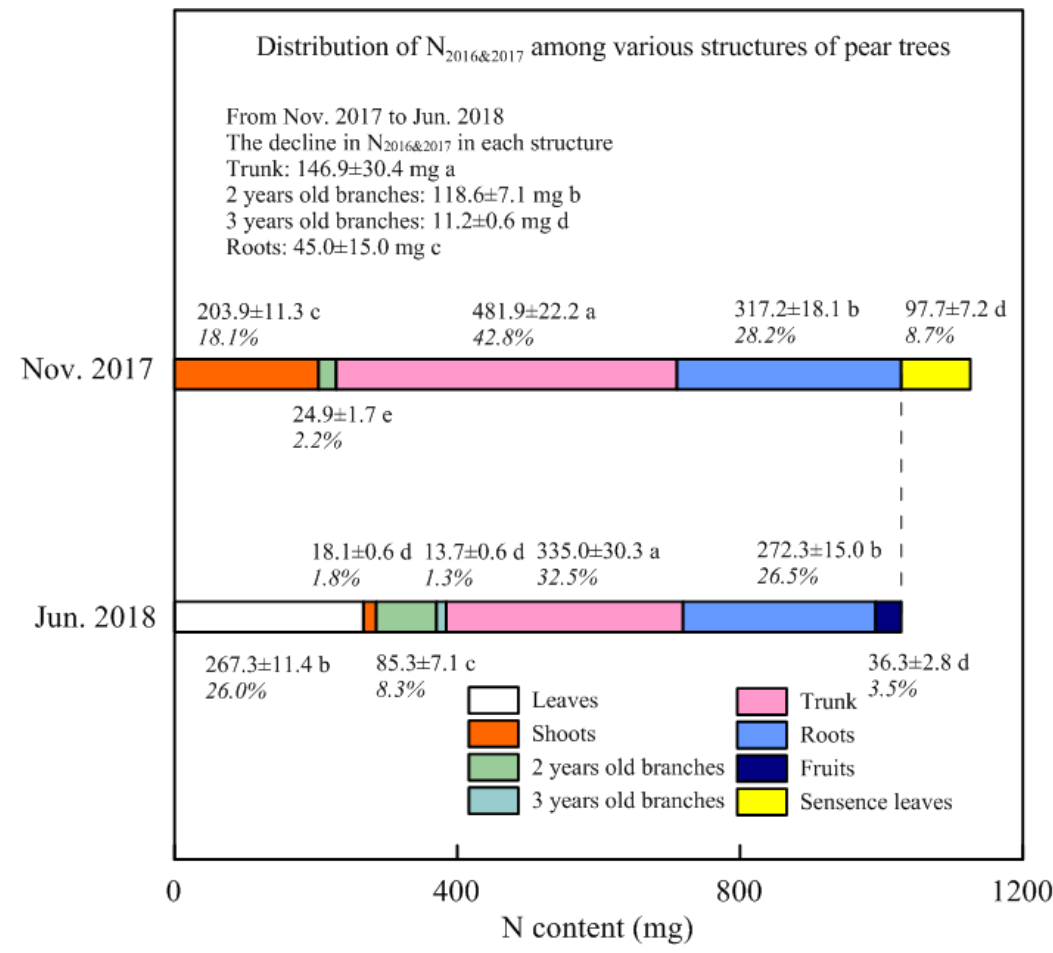

Figure 3. The distribution of $\mathrm{N}_{2016 \& 2017}$ among various structures of pear trees. $\mathrm{N}_{2016 \& 2017}$ means amount of fertilizer-N derived in 2016 and 2017. The numbers mean the $\mathrm{N}_{2016 \& 2017}$ amount in each structure. Different small letters for each sampling time indicate significant differences $(p<0.05)$ among organs. The italic numbers means the ratio of $\mathrm{N}_{2016 \& 2017}$ in each structure to total $\mathrm{N}_{2016 \& 2017}$ in a whole tree. 


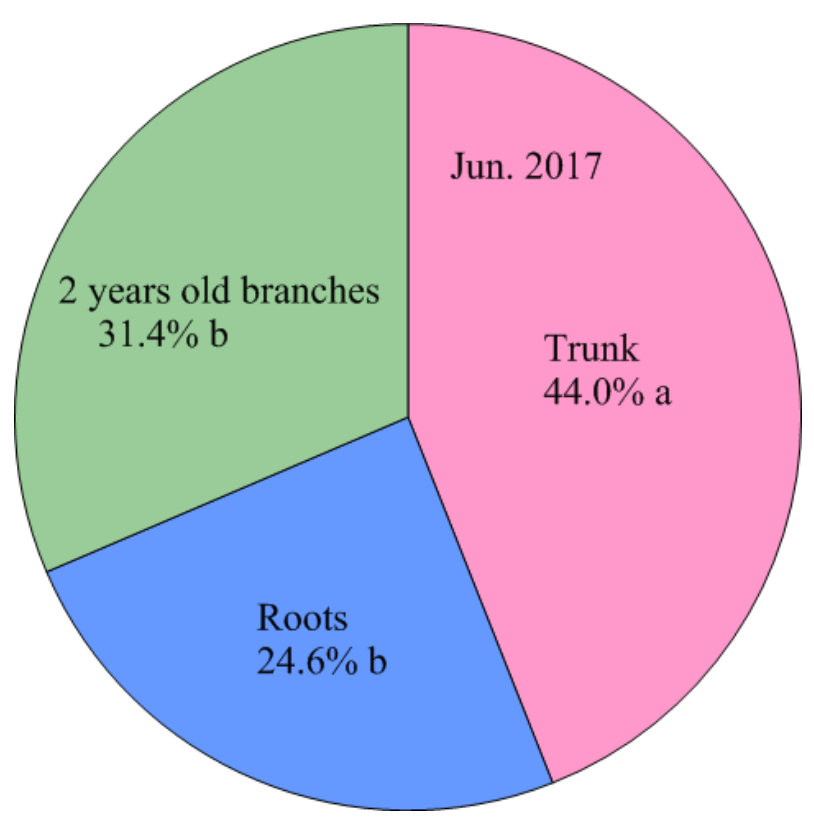

Figure 4. The ratio of $\mathrm{N}_{2016}$ supplied by each perennial structure of pear trees to total remobilized $\mathrm{N}_{2016}$ in spring of 2017. $\mathrm{N}_{2016}$ means amount of fertilizer-N derived in 2016. Different small letters indicate significant differences $(p<0.05)$ among organs.

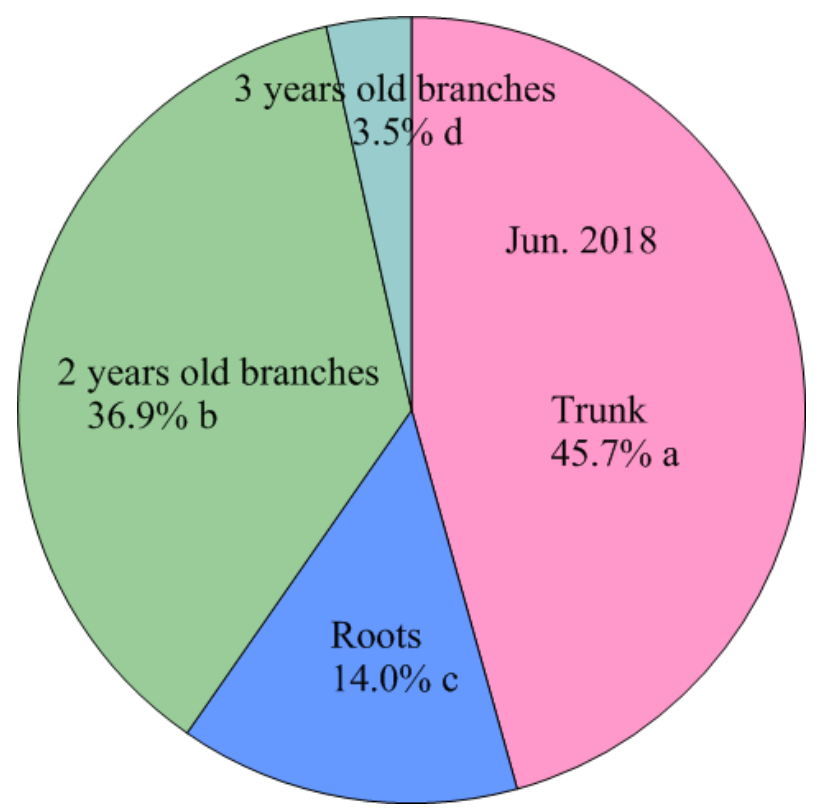

Figure 5. The ratio of $\mathrm{N}_{2016 \& 2017}$ supplied by each perennial structure of pear trees to total remobilized $\mathrm{N}_{2016 \& 2017}$ in spring of 2018. $\mathrm{N}_{2016 \& 2017}$ means amount of fertilizer-N derived in 2016 and 2017. Different small letters indicate significant differences $(p<0.05)$ among organs.

From June to November 2017, the increase in $\mathrm{N}_{2016}$ in the trunk was $26.5 \mathrm{mg}$ (Figure 2), which accounted for $56.7 \%$ of the $\mathrm{N}_{2016}$ withdrawn from leaves (Figure 6). The $\mathrm{N}_{2016}$ withdrawn from the senescent leaves to the shoots and roots was 11.9 and $8.0 \mathrm{mg}$, respectively, which were significantly lower than that to the trunk. No significant differences were observed in $\mathrm{N}_{2016}$ of the 2 year old branches between June and November in 2017. 


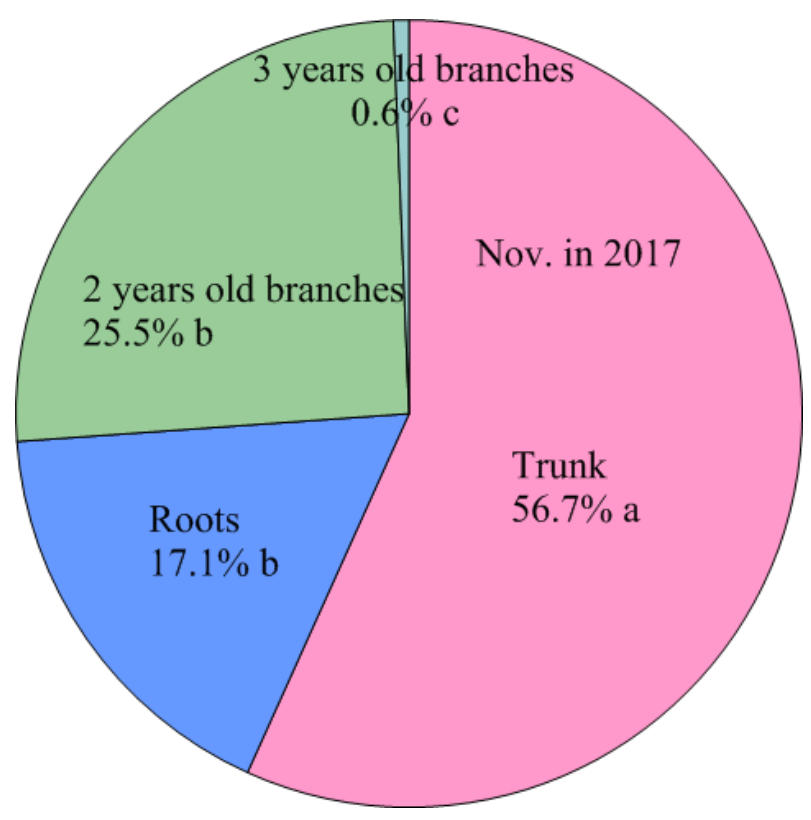

Figure 6. The distribution of $\mathrm{N}_{2016}$, withdrawn from senescent leaves, among various perennial structures of pear trees in autumn 2017. $\mathrm{N}_{2016}$ means amount of fertilizer-N derived in 2016. Different small letters indicate significant differences $(p<0.05)$ among organs.

\section{Discussion}

\section{1. $N$ Absorbed from Soil and Fertilizer}

The total $\mathrm{N}$ uptake from native soil and fertilizer increased with the age of pear trees, which is consistent with the results of Neto et al. [10]. From 2016 to 2018, the N requirement increased with dry mass weight of pear trees (Table 3), and the $\mathrm{N}$ absorption capacity of root systems improved, which resulted in more $\mathrm{N}$ being taken up by pear trees. In 2017, the increment in the total $\mathrm{N}$ of the whole trees from June to November was significantly higher than that from spring to June, because the capacity of $\mathrm{N}$ uptake from the soil was low due to the low soil temperature and activity of root systems in early spring [10,42,43]. Especially, the higher temperature and precipitation during the summer was helpful to the mineralization of soil organic matters [44-46], resulting in higher inorganic $\mathrm{N}$ content in soil, which can be taken up by pear trees. However, the opposite phenomenon was observed in the $\mathrm{N}$ derived from fertilizer, which resulted from the fertilizer being supplied in early spring and the fertilizer $\mathrm{N}$ concentration in the soil being relatively low after June.

\subsection{Remobilization of the Stored $N$ during Spring}

$\mathrm{N}$ taken up in the former years was the main $\mathrm{N}$ source of leaves during the early spring. In June 2017, the $\mathrm{N}_{2016}$ in the leaves approximately accounted for $28.1 \%$ of the total $\mathrm{N}_{2016}$ in a whole tree, the corresponding value was $26.0 \%$ in June 2018 (Figures 2 and 3). Due to low soil temperature in early spring, the activity of root systems was low and $\mathrm{N}$ absorption capacity was weak, thus the growth of new organs was supported by the $\mathrm{N}$ stored in perennial tissues in pear trees. Similar results were determined by Neto et al. [10] for young pear trees. However, approximately $45 \%$ of storage $N$ was partitioned to new growth of 5 years-old pear trees [30]. The reason for this discrepancy may be the weak capability of $\mathrm{N}$ storage of young pear trees, due to low biomass of perennial organs in our study. The storage $\mathrm{N}$ remobilized in the shoots and fruits was far lower than that in the leaves, and similar results were obtained by Kim et al. [19] and Bravo et al. [29]. The dry mass weight and $\mathrm{N}$ concentration in leaves were far higher than that in shoots and fruits, which resulted in the higher total $\mathrm{N}$ and stored $\mathrm{N}$ remobilized in leaves. 


\subsection{Storage N Derived from Perennial Structures in Spring}

The storage $\mathrm{N}$ in the trunk was important to sustain the new growth in the next spring, approximately providing $32.7 \%$ of $\mathrm{N}_{2016}$ and $30.5 \%$ of $\mathrm{N}_{2016 \& 2017}$ stored in the trunk to new organs in early spring 2017 and 2018 (Figures 2 and 3), respectively. Approximately $81.8 \%$ of $\mathrm{N}_{2016}$ and $58.4 \%$ of $\mathrm{N}_{2016 \& 2017}$ stored in the 2 year old branches were provided for new growth in spring of 2017 and 2018, respectively. These indicated that the trunk and 2 year old branches of young pear trees play an essential role in the process of storage $\mathrm{N}$ remobilization. Similar conclusions were reported by Sanchez et al. [30] and Neto et al. [10] for pear trees, Millard and Neilsen [28] for apple trees and Bravo et al. [29] for walnut trees. A significantly lower $\mathrm{N}$ concentration in the trunk and 2 year old branches were observed in June than that in last November (Table 3). From the November to next June, the decline in the $\mathrm{N}$ concentration and increase in dry mass of the trunk and 2 year old branches indicated that mass stored $\mathrm{N}$ in these tissues was remobilized by new organs during the spring.

Approximately $16.7 \%$ of the $\mathrm{N}_{2016}$ stored in the roots was consumed by new organs in the spring of 2017 , but only $14.2 \%$ of the $\mathrm{N}_{2016 \& 2017}$ stored in the roots was recovered in new organs in the spring of 2018. The root system grew faster in 2018 than that in 2017, which was proven by the higher ratio of root dry weight to an entire tree in 2018. These resulted in more $\mathrm{N}$ being stored in roots. The $\mathrm{N}$ concentration was constant (1.2-1.3\%) from November to next June (Table 3), the dry mass weight and $\mathrm{N}$ content in roots increased, in particular the significantly differences from November of 2017 to June of 2018 were observed. These indicated that although the $\mathrm{N}$ stored in roots was also the source of new growth in spring, the $\mathrm{N}$ taken up by roots from the soil was higher than that supplied by the roots. The $\mathrm{N}$ restored in root systems during the autumn mainly met the requirement of root growth in young pear trees grafted on the vigorous rootstocks during the next spring.

In the spring of 2017 and 2018, the stored $N$ remobilized in new organs were supplied by the trunk, 2 year old branches and roots in our study (Figures 4 and 5). However, the studies on the pear trees (Pyrus communis L.) grafted on the quince rootstocks show that almost all stored $\mathrm{N}$ recovered in new growth is supplied by the trunk and old shoots [10]. In our study, the trunk dry mass weight increased by $52 \%$ and $592 \%$ during the first and second year after planting, respectively, while the corresponding values are $39 \%$ and $191 \%$ in the studies on the dwarfing rootstocks [10], and similar trends were observed in the shoots. The aboveground of young pear trees grafted on the vigorous rootstocks grew more vigorously than that on the dwarfing rootstocks. However, slower growth rate of the root systems in young trees grafted on the vigorous rootstocks was observed by Zhao et al. [35], as compared with that on the dwarfing rootstocks. Therefore, more nutrients were used to meet the requirement of the vigorous structures growth, and less $\mathrm{N}$ remobilized in new organs was derived from the trunk and old shoots of the trees grafted on the vigorous rootstocks, as compared with the that of the dwarfing rootstocks. The studies on the seven year old pear trees grafted on quince rootstocks indicated that the reserve $\mathrm{N}$ stored in the roots is utilized for new growth, the aboveground parts grow vigorously, but biomass of the root system keeps constant [30,31]. These results also showed that when the root system stops growing and the nutrient requirement of their own growth decreases, the roots provide $\mathrm{N}$ for supporting the new growth of mature pear trees grafted on the dwarfing rootstocks. The study on the mature pear trees grafted onto vigorous rootstocks indicated that the remobilized $\mathrm{N}$ in spring were mainly supported by the root [36], maybe because the mass weight of each structure in mature pear trees was relatively stable, therefore the $\mathrm{N}$ taken up in previous years was mainly stored in root systems.

\subsection{Redistribution of the Stored $N$ Withdrawn from Senescent Leaves}

Approximately $46.7 \mathrm{mg} \mathrm{N}_{2016}$ in the leaves was mobilized to the perennial tissues during autumn 2017, which accounted for approximately $61.5 \%$ of the $\mathrm{N}_{2016}$ in the leaves in the June. The similar results were reported by Sanchez and Righetti [8] for pear trees and Niederholzer et al. [9] for peach trees. The $\mathrm{N}$ content in leaves was significantly higher 
than that in other tissues in June, which approximately accounted for $40 \%$ of total $\mathrm{N}$ in a whole tree, thus the $\mathrm{N}$ withdrawn from leaves effectively avoided the $\mathrm{N}$ losses during deciduous periods and increased the $\mathrm{N}$ use efficiency.

Until November, approximately $56.7 \%$ of the $\mathrm{N}_{2016}$ withdrawn from the senescent leaves were recovered in the trunk, which were far higher than that recovered in the branches and roots (Figure 4). A significant increase in total $\mathrm{N}$ content was also detected in the trunk, which resulted in the improvement in $\mathrm{N}$ concentration during this period (Table 3). These results proved that the trunk absorbed $\mathrm{N}$ from the soil and senescent leaves during the summer and autumn, which sustained new growth in the next spring.

From June to November 2017, approximately $25.5 \%$ of the $\mathrm{N}_{2016}$ withdrawn from the senescent leaves was transferred to the shoots (Figure 4), which led to a significant increase in $\mathrm{N}_{2016}$ in the shoots. An increase in the total $\mathrm{N}$ in the shoots was also observed, which was helpful in supporting the new growth during the next spring. However, there were no significant increases in $\mathrm{N}_{2016}$ in the 2 year old branches. The total $\mathrm{N}$ increase in this tissue only accounted for $1 \%$ of that in a whole tree, indicating that the 2 year old branches of young pear trees were not the main $\mathrm{N}$ storage tissues for supporting new growth in the next spring. N uptake of 2 year old branches was only used to meet the requirements of growth during this period. These results were confirmed by the fact that the $\mathrm{N}_{2016 \& 2017}$ derived from the 3 year old branches only accounted for $3.5 \%$ of $\mathrm{N}_{2016 \& 2017}$ recovered in new tissues in the spring of 2018 (Figure 6).

In our study, the total $\mathrm{N}$ in the roots significantly increased from June to November 2017, indicating that the root system was one of the main N storage structures during the winter. Studies on apple [47], sycamore [22], pear [31] and nectarine tress [6] have reported similar conclusions. About $17.1 \%$ of NFF withdrawn from the senescent leaves was recovered in roots (Figure 4), which were also significantly lower than that in trunk and shoots. These also proved that the trunk and 2 year old branches played a more important role than the roots in the cycling process of storage $\mathrm{N}$, the $\mathrm{N}$ stored in root systems was mainly used to supply the root growth in young pear trees grafted on vigorous rootstocks during the next spring.

\section{Conclusions}

During the early spring, more than $25 \%$ of the $\mathrm{N}$ taken up in former years within a whole young pear tree was remobilized in the leaves, which was far higher than that in the shoots and fruits. Most of the storage $\mathrm{N}$ remobilized in new growth was supplied by the trunk and shoots (n-1), which were significantly higher than that by the root systems. From June to November, approximately $82.2 \%$ of the storage $\mathrm{N}$ withdrawn from senescent leaves was recovered in trunk and shoots, and only about $17.1 \%$ of storage $\mathrm{N}$ withdrawn from senescent leaves was recovered in roots. The trunk and 2 year old branches played a more important role than the roots in the cycling process of storage $\mathrm{N}$ in young pear trees. However, as compared with that on the dwarfing rootstocks, more storage $\mathrm{N}$ remobilized in new growth was supplied by the root system of the young pear trees grafted on the vigorous rootstocks. This may be because more $\mathrm{N}$ was needed to meet the requirement of the vigorous aboveground structures' growth, and less $\mathrm{N}$ remobilized in new organs was derived from the aboveground structures of young pear trees grafted on the vigorous rootstocks.

Author Contributions: Conceptualization, Y.W. and S.L.; Methodology, Y.W. and S.L.; Investigation, Y.W., Y.Q. and M.S.; Resources, Y.W.; Data curation, Y.W., Y.Q. and M.S.; Visualization, Y.W. and M.S.; Writing-original draft, Y.W.; Writing-review \& editing, Y.W. and S.L.; Funding acquisition, S.L. All authors have read and agreed to the published version of the manuscript.

Funding: The project was financed by the Presidential Foundation of the Beijing Academy of Forestry and Pomology Sciences, Project number: 201902; the National Key Technology R\&D Program of China, Project number: 2014BAD16B03-3; and the Central Public-interest Scientific Institution Basal Research Fund (Farmland Irrigation Research Institute, CAAS), Project number: FIRI2016-19. 
Institutional Review Board Statement: Not applicable.

Informed Consent Statement: Not applicable.

Data Availability Statement: The data presented in this study are available on request from the corresponding author.

Conflicts of Interest: The authors declare that they have no conflict of interest.

\section{References}

1. Thitithanakul, S.; Pétel, G.; Chalot, M.; Beaujard, F. Supplying nitrate before bud break induces pronounced changes in nitrogen nutrition and growth of young poplars. Funct. Plant Biol. 2012, 39, 795-803. [CrossRef] [PubMed]

2. Roccuzzo, G.; Scandellari, F.; Allegra, M.; Torrisi, B.; Stagno, F.; Mimmo, T.; Zanotelli, D.; Gioacchini, P.; Millard, P.; Tagliavini, M. Seasonal dynamics of root uptake and spring remobilisation of nitrogen in field grown orange trees. Sci. Hortic. 2017, 226, 223-230. [CrossRef]

3. Maity, A.; Babu, K.D.; Sarkar, A. Guidelines for fertilizer use in pomegranate orchards based on seasonal uptake and partitioning of nutrients. Sci. Hortic. 2019, 252, 138-148. [CrossRef]

4. Zarate-Valdez, J.L.; Muhammad, S.; Saa, S.; Lampinen, B.D.; Brown, P.H. Light interception, leaf nitrogen and yield prediction in almonds: A case study. Eur. J. Agron. 2015, 66, 1-7. [CrossRef]

5. Sanchez, E.E.; Righetti, T.L.; Sugar, D.; Lombard, P.B. Seasonal differences, soil texture and uptake of newly absorbed nitrogen in field-grown pear trees. J. Hortic. Sci. 1990, 65, 395-400. [CrossRef]

6. Tagliavini, M.; Millard, P.; Quartieri, M.; Marangoni, B. Timing of nitrogen uptake affects winter storage and spring remobilisation of nitrogen in nectarine (Prunus persica var. nectarina) trees. Plant Soil 1999, 211, 149-153. [CrossRef]

7. Malaguti, D.; Tagliavini, M.; Masia, A.; Marangoni, B.; Gioacchini, P.; Vittori Antisari, L.; Millard, P. Dynamic of root uptake of ammonium and nitrate by pear (Pyrus communis L.) trees after growth resumption in spring. In Plant Nutrition-Food Security and Sustainability of Agro-Ecosystems; Springer: Berlin/Heidelberg, Germany, 2001; pp. 124-125.

8. Sanchez, E.E.; Righetti, T.L. Tree nitrogen status and leaf canopy position influence postharvest nitrogen accumulation and efflux from pear leaves. J. Am. Soc. Hortic. Sci. 1990, 115, 934-937. [CrossRef]

9. Niederholzer, F.J.A.; de Jong, T.M.; Saenz, J.L.; Muraoka, T.T.; Weinbaum, S.A. Effectiveness of fall versus spring soil fertilization of field-grown peach trees. J. Am. Soc. Hortic. Sci. 2001, 125, 644-648. [CrossRef]

10. Neto, C.; Carranca, C.; Clemente, J.; de Varennes, A. Nitrogen distribution, remobilization and re-cycling in young orchard of non-bearing 'Rocha' pear trees. Sci. Hortic. 2008, 118, 299-307. [CrossRef]

11. Arrobas, M.; Ferreira, I.Q.; Freitas, S.; Verdial, J.; Rodrigues, M.A. Guidelines for fertilizer use in vineyards based on nutrient content of grapevine parts. Sci. Hortic. 2014, 172, 191-198. [CrossRef]

12. Jordan, M.O.; Wendler, R.; Millard, P. Autumnal $N$ storage determines the spring growth, $N$ uptake and $N$ internal cycling of young peach trees. Trees 2012, 26, 393-404. [CrossRef]

13. Pescie, M.A.; Borda, M.P.; Ortiz, D.P.; Landriscini, M.R.; Lavado, R.S. Absorption, distribution and accumulation of nitrogen applied at different phenological stages in southern highbush blueberry (Vaccinium corymbosum interspecific hybrid). Sci. Hortic. 2018, 230, 11-17. [CrossRef]

14. Vajari, M.A.; Moghadam, J.F.; Eshghi, S. Influence of late season foliar application of urea, boric acid and zinc sulfate on nitrogenous compounds concentration in the bud and flower of Hayward kiwifruit. Sci. Hortic. 2018, 242, 137-145. [CrossRef]

15. Vajari, M.A.; Eshghi, S.; Moghadam, J.F.; Gharaghani, A. Late season mineral foliar application improves nutritional reserves and flowering of kiwifruit. Sci. Hortic. 2018, 232, 22-28. [CrossRef]

16. Neilsen, D.; Millard, P.; Neilsen, G.H.; Hogue, E.J. Sources of N used for leaf growth in a high density apple (Malus domestica) orchard irrigated with ammonium nitrate solution. Tree Physiol. 1997, 17, 733-739. [CrossRef] [PubMed]

17. Cheng, L.; Fuchigami, L.H. Growth of young apple trees in relation to reserve nitrogen and carbohydrates. Tree Physiol. 2002, 22, 1297-1303. [CrossRef] [PubMed]

18. Weinbaum, S.; Kessel, C.V. Quantitative estimates of uptake and internal cycling of ${ }^{14} \mathrm{~N}$-labeled fertilizer in mature walnut trees. Tree Physiol. 1998, 18, 795-801. [CrossRef] [PubMed]

19. Kim, Y.K.; Lim, C.S.; Kang, S.M.; Cho, J.L. Root storage of nitrogen applied in autumn and its remobilization to new growth in spring of persimmon trees (Diospyros kaki cv. Fuyu). Sci. Hortic. 2009, 119, 193-196. [CrossRef]

20. Taylor, B.K. Storage and mobilization of nitrogen in fruit trees: A review. J. Aust. Inst. Agric. Sci. 1967, 33, 23-29.

21. May, L.H. The nitrogen nutrition of the peach tree II-Storage and mobilization of nitrogen in mature trees. Aust. J. Biol. Sci. 1967, 20, 389-411.

22. Millard, P.; Proe, M.F. Leaf demography and the seasonal internal cycling of nitrogen in sycamore (Acer pseudoplatanus L.) seedlings in relation to nitrogen supply. New Phytol. 1991, 17, 587-596. [CrossRef]

23. Toselli, M.; Flore, J.A.; Zavalloni, C.; Marangoni, B. Nitrogen partitioning in apple trees as affected by application time. Horttechnology 2000, 10, 136-140. [CrossRef]

24. Frak, E.; Millard, P.; Le Roux, X.; Guillaumie, S.; Wendler, R. Coupling sap flow velocity and amino acid concentrations as an alternative method to ${ }^{15} \mathrm{~N}$ labeling for quantifying nitrogen remobilization by walnut trees. Plant Physiol. 2002, 130, 1043-1053. [CrossRef] [PubMed] 
25. Grassi, G.; Millard, P.; Wendler, R.; Minotta, G.; Tagliavini, M. Measurement of xylem sap aminoacid concentrations in conjunction with whole tree transpiration estimates spring $N$ remobilization by cherry (Prunus avium L.) trees. Plant Cell Environ. 2002, 25, 1689-1699. [CrossRef]

26. San-Martino, L.; Sozzi, G.O.; San-Martino, S.; Lavado, R.S. Isotopically-labelled nitrogen uptake and partitioning in sweet cherry as influenced by timing of fertilizer application. Sci. Hortic. 2010, 126, 42-49. [CrossRef]

27. Gomez, L.; Vercambre, G.; Jordan, M.O. Spatial-temporal management of nitrogen and carbon on the peach tree (Prunus persicae L. Batsch.). Sci. Hortic. 2020, 273, 109613. [CrossRef]

28. Millard, P.; Neilsen, G.H. The influence of nitrogen supply on the uptake and remobilization of stored $N$ for the seasonal growth of apple Trees. Ann. Bot. 1989, 63, 301-309. [CrossRef]

29. Bravo, K.; Marcolini, G.; Sorrenti, G.; Baldi, E.; Quartieri, M.; Toselli, M. Effect of time of application on nitrogen uptake, partitioning, and remobilization in walnut trees. J. Plant Nutr. 2017, 40, 719-725. [CrossRef]

30. Sanchez, E.E.; Righetti, T.L.; Sugar, D.; Lombard, P.B. Recycling of nitrogen in field-grown 'Comice' pears. J. Hortic. Sci. 1991, 66, 479-486. [CrossRef]

31. Sanchez, E.E.; Righetti, T.L.; Sugar, D.; Lombard, P.B. Effects of timing of nitrogen application on nitrogen partitioning between vegetative, reproductive and structural components of mature 'Comice' pears. J. Hortic. Sci. 1992, 67, 51-58. [CrossRef]

32. Tagliavini, M.; Quartieri, M.; Millard, P. Remobilised nitrogen and root uptake of nitrate for spring leaf growth, flowers and developing fruits of pear (Pyrus communis L.) trees. Plant Soil 1997, 195, 137-142. [CrossRef]

33. Khemira, H.; Azarenko, A.N.; Sugar, D.; Righetti, T.L. Postharvest nitrogen application effect on ovule longevity of 'Comice' pear trees. J. Plant Nutr. 1998, 21, 405-411. [CrossRef]

34. Quartieri, M.; Millard, P.; Tagliavini, M. Storage and remobilisation of nitrogen by pear (Pyrus communis L.) trees as affected by timing of N supply. Eur. J. Agron. 2002, 17, 105-110. [CrossRef]

35. Zhao, Y.; Sun, M.; Liang, Z.; Li, H.; Yu, F.; Liu, S. Analysis of contrast iron chlorosis tolerance in the pear cv. 'Huangguan' grafted onto Pyrus betulifolia and quince A grown in calcareous soils. Sci. Hortic. 2020, 271, 109-488. [CrossRef]

36. Jiang, H.; Li, H.; Zhao, M.; Mei, X.; Kang, Y.; Dong, C.; Xu, Y. Strategies for timing nitrogen fertilization of pear trees based on the distribution, storage, and remobilization of ${ }^{15} \mathrm{~N}$ from seasonal application of $\left({ }^{15} \mathrm{NH}_{4}\right)_{2}$ SO. J. Integr. Agric. 2020, 19, 1340-1353. [CrossRef]

37. Oland, K. Changes in the content of dry matter and major nutrient element of apple foliage during senescence and abscission. Physiol. Plant. 1963, 16, 682-692.

38. Deng, X.; Weinbaum, S.A.; Dejong, T.M.; Muraoka, T.T. Utilization of nitrogen from storage and current-year uptake in walnut spurs during the spring flush of growth. Physiol. Plant. 1989, 75, 492-498. [CrossRef]

39. Millard, P. Ecophysiology of the internal cycling of nitrogen for tree growth. J. Plant Nutr. Soil Sci. 1996, 159, 1-10. [CrossRef]

40. Götz, K.P.; Naher, J.; Fettke, J.; Chmielewski, F.M. Changes of proteins during dormancy and bud development of sweet cherry (Prunus avium L.). Sci. Hortic. 2018, 239, 41-49. [CrossRef]

41. Carranca, C.; de Varennes, A.; Rolston, D.E. Variation in $N$-recovery of winter wheat under Mediterranean conditions studied with ${ }^{15} \mathrm{~N}$-labelled fertilizers. Eur. J. Agron. 1999, 11, 145-155. [CrossRef]

42. Muñoz, N.; Guerri, J.; Legaz, F.; Primo Millo, E. Seasonal uptake of ${ }^{15} \mathrm{~N}$-nitrate and distribution of absorbed nitrogen in peach trees. Plant Soil 1993, 150, 263-269. [CrossRef]

43. Wu, Y.; Sun, M.; Liu, J.; Wang, W.; Liu, S. Fertilizer and soil nitrogen utilization of pear trees as affected by the timing of split fertilizer application in rain-fed orchard. Sci. Hortic. 2019, 252, 363-369. [CrossRef]

44. Mason-Jones, K.; Vrehen, P.; Koper, K.; Wang, J.; van der Putten, W.H.; Veen, G.F. Short-term temperature history affects mineralization of fresh litter and extant soil organic matter, irrespective of agricultural management. Soil Biol. Biochem. 2020, 150, 107985. [CrossRef]

45. Bradford, M.A.; Wieder, W.R.; Bonan, G.B.; Fierer, N.; Raymond, P.A.; Crowther, T.W. Managing uncertainty in soil carbon feedbacks to climate change. Nat. Clim. Chang. 2016, 6, 751-758. [CrossRef]

46. Lopez-Sangil, L.; Hartley, I.P.; Rovira, P.; Casals, P.; Sayer, E.J. Drying and rewetting conditions differentially affect the mineralization of fresh plant litter and extant soil organic matter. Soil Biol. Biochem. 2018, 124, 81-89. [CrossRef]

47. Tromp, J. Nutrient reserves in roots of fruit trees, in particular carbohydrates and nitrogen. Plant Soil 1983, 71, 401-413. [CrossRef] 